\title{
FOKALISASI DALAM NOVEL SEMUA IKAN DI LANGIT KARYA ZIGGY ZEZSYAZEOVIENNAZABRIZKIE (SUATU KAJIAN NARATOLOGI)
}

\author{
Rendy Pribadi' ${ }^{1}$ M. Rinzat Iriyansah ${ }^{2}$ \\ ${ }^{1}$ Program Magister Pendidikan Bahasa, Universitas Negeri Jakarta \\ ${ }^{2}$ Prodi Pendidikan Bahasa Inggris, Fakultas Bahasa dan Seni, Universitas Indraprasta PGRI \\ ${ }^{1}$ Rendypribadi_pb18s2@mahasiswaunj.ac.id, ${ }^{2}$ Rinzat@gmail.com
}

\begin{abstract}
Abstrak
Penelitian ini bertujuan untuk mengetahui simbol dalam novel Semua Ikan Di Langit karangan Ziggy Zezsyazeoviennazabrizkie dari unsur cerita (narasi) dialog, dan laku dari tokoh-tokohnya. Terdapat sebuah teknik yang berbeda saat beberapa tokoh menceritakan kehidupannya, mulai dari simbol ikan, bus, dan kecoa serta obyek beliau yang selalu hadir kala di awal dan akhir bahkan seluruh bab. Penelitian ini menggunakan pendekatan kualitatif dengan metode pengumpulan data menggunakan metode kepustakaan. Teknik analisis isi. Penulis menemukan sejumlah teknik bercerita; 1. Fokalisasi interen ("saya") berdasarkan narator, 2. Fokalisasi ekstern dengan bentuk simbol, 3. Cerita harmonis dan miris dalam satu bingkai novel tersebut.
\end{abstract}

Kata Kunci: Fokalisasi, Naratologi

\begin{abstract}
This study aims to find out the symbols in the novel All Fish in the Sky by Ziggy Zezsyazeoviennazabrizkie from the elements of the story (narration) dialogue, and the behavior of the characters. There is a different technique when some characters tell their lives, ranging from symbols of fish, buses, and cockroaches and objects that are always present at the beginning and end of all chapters. This study uses a qualitative approach with data collection methods using the library method. Content analysis technique. The author finds a number of storytelling techniques; 1. Internal vocalization ("I") based on the narrator, 2. External vocalization with symbolic form, 3. Harmonious and sad story in one frame of the novel
\end{abstract}

Keywords: Focalisation, Naratology

\section{PENDAHULUAN}

Jika kita hendak memahami strukturalisme dalam naratologi melalui pengertian struktur sebagai "sebuah bangun abstrak yang terdiri atas sejumlah komponen yang berkaitan satu sama lain untuk membentuk struktur itu, ada dua aspek penting yang perlu digarisbawahi (Ridho, 2013). Pertama, yang penting di dalam struktur adalah abstraksi atau model, bukan benda atau material. Dari segi ini, pandangan dunia yang disebut strukturalisme pada dasarnya lebih dekat dengan asumsi-asumsi idealisme daripada realisme. Kesenjangan ini yang di kemudian hari hendak dicoba diatasi dalam perkembangan strukturalisme itu sendiri. 
Kedua, struktur mengandaikan adanya hubungan (relasi) antar komponen (unsur) yang membentuknya, yang disebut juga dengan istilah difference. Berbeda dengan positivisme yang cenderung mengutamakan kausalitas yang ketat sebagai landasan dalam setiap relasi unsur-unsur alamiah maupun sosial, strukturalisme lebih menekankan relasi maknawi atau simbolik, dan hal ini membuka jalan bagi ilmu-ilmu sosial dan budaya untuk dapat keluar dari dominasi paradigma positivistik ilmu-ilmu alam.

Levi-Strauss (2005, 48) merintis jalan itu dengan ungkapannya yang sugestif:...dalam suatu tatanan realitas yang lain, fenomena-fenomena kekerabatan merupakan fenomena dengan jenis yang sama seperti fenomena linguistik. Dengan mempergunakan sebuah metode yang analog dengan metode yang menyangkut bentuk (kalau bukan menyangkut isi/kandungannya) seperti pada bentuk yang diperkenalkan melalui fonologi, bisakah sosiolog mencapai kemajuan sebuah ilmu yang analog dengan kemajuan yang baru saja mengambil tempat dalam ilmu-ilmu bahasa ini ? (Ridho, 2013) (cetak miring dari Levi-Strauss)

...dalam suatu tatanan realitas yang lain, fenomena-fenomena kekerabatan merupakan fenomena dengan jenis yang sama seperti fenomena linguistik. Dengan mempergunakan sebuah metode yang analog dengan metode yang menyangkut bentuk (kalau bukan menyangkut isi/kandungannya) seperti pada bentuk yang diperkenalkan melalui fonologi, bisakah sosiolog mencapai kemajuan sebuah ilmu yang analog dengan kemajuan yang baru saja mengambil tempat dalam ilmu-ilmu bahasa ini? (cetak miring dari Levi-Strauss).

Konsep struktural mendapat kritik dari ilmu para ilmuwan kontemporer. Hal ini karena yang semula mengambil bentuk strukturalisme languae dan parole- hanya mengambil bentuk abstrak dan wujud nyata dari sebuah bahasa, kini bisa diwujudkan dalam ilmu sastra yang lebih fleksibel dan interdisipliner terhadap ilmu lainnya, misalya culture studies dan sosiohistoris yang menganalisis teks dari tataran riwayat dan penceritaan. Subdisiplin ilmu lainya seperti Beberapa subdisiplin yang kemudian merebak di antaranya adalah naratologi psikoanalitik, naratologi feminis, studi cerita yang berorientasi cultural studies, dan studi cerita pascakolonial (Ridho, 2013). Konsep yang diungkapkan oleh Fludernik $(2005,37)$ bahwa perkembangan ini mengarah pada;

"reorientation and diversification of narrative theories, producing a series of subdisciplines that arose in reaction to post-structuralism and the paradigm shift to cultural studies.

Setelah menekankan pada aspek interdisipliner, selanjutnya menentukan dikotomi dari naratologi itu sendiri. Dalam pendeskripsian narativitas itu, para naratolog awal memang masih mendasarkan diri pada model sintaksis dalam strukturalisme. Karena itu, studi mereka masih menekankan pada salah satu tataran, yaitu story, di antara tiga levels of narrative (tataran cerita) yang terdiri dari tataran story, text, dan narration (Ridho, 2013).

Story dalam hal ini didefinisikan oleh Rimmon-Kenan (2002) sebagai "the narrated events, abstracted from their disposition in the text and reconstructed in their chronological order, together with the participants in these events."

Dalam tataran ini, yang dipersoalkan adalah bagaimana menentukan unsur terkecil cerita dan membangun kaidah kombinasi dan permutasinya. Konsep kejadian (event) dan peran tokoh menjadi sangat menentukan dalam hal ini, kemudian berbagai 
terminologi diajukan oleh para naratolog awal ini untuk menjawab persoalan tersebut, seperti fungsi, kalimat naratif, cardinal function, catalyzer, sphere of action, dan aktan. Dalam konteks pencarian tata cerita di tataran story itulah narativitas pada mulanya dipahami (Ridho, 2013).

Pada perkembangan selanjutnya, penelitian dalam naratologi bergeser dari perhatian terhadap tataran story (riwayat) ke tataran text (teks), yaitu yang mempertanyakan bagaimana kombinasi (urutan kronologis) kejadian dalam story mengalami perubahan dalam tataran teks. Dalam rumusan Rimmon-Kenan (2002), tataran ini diartikan sebagai "...

what we read. In it, the events don't

necessarily appear in chronological order, the characteristics of the participants is dispersed throughout, and all the items of narrative content are filtered through some prism or perspective ('focalizer')."

Dengan kata lain, jika riwayat adalah hasil abstraksi, maka teks adalah sumber abstraksi itu. Menurut Abbot (2007, 41), jika dikemukakan dalam istilah Saussure tentang pembedaan penanda dan petanda, maka teks adalah penanda sedangkan riwayat adalah petandanya. Meskipun urutan kronologis biasanya dianggap sebagai urutan yang normal dan alamiah, para naratolog memandangnya sebagai semata-mata sebuah konvensi tentang waktu karena pada dasarnya waktu juga bergerak secara serempak dan banyakarah (multiliniar). Karena itu, mereka membuat dikotomi penting yang khas struktural, yaitu waktu riwayat (story time) dan waktu teks (text time). Dalam tataran teks, kejadiankejadian tidak mesti berurutan secara kronologis atau mengikuti waktu riwayat, tetapi berada dalam apa yang disebut sebagai waktu teks.

Penyimpangan dari urutan kronologis ini diistilahkan sebagai anakroni (Bal 1997, 83). Jadi, pada dasarnya fenomena anakronilah yang diteliti dalam tataran teks itu. Dalam konteks ini, studi Genette (1980) yang ekstensif dalam tataran teks memberi arah yang inspiratif dalam pengembangan naratologi selanjutnya. Konsep-konsep penting, seperti durasi, order, frekuensi, dan fokalisasi kemudian menjadi topik studi yang subur bagi peneliti naratologi selanjutnya. Konsep fokalisasi-yang menggantikan konsep lama seperti point of view dan perspektif - memicu perdebatan, tetapi juga memberi jalan pada pendekatan naratologi kognitif akhir-akhir ini (lihat, misalnya, Hühn, Schmid, dan Schönert 2009).

Aspek lainnya dalam tataran teks adalah karakterisasi. Aspek yang menghadirkan karakter tidak hanya bekerja individu tetapi ia bekerja dengan sebuah kode. Cara menemukannya menurut terminologi Barthes yakni dengan menggunakan sumbu semantik (semantic axes) yang didasari oleh complexes of descriptions (Margolin, 2007);

“...they are not open to direct perception by us, and can be known only through textual descriptions or inferences based on those descriptions. In fact, they are these complexes of descriptions, not having any independent worldly existence."

Pada tataran ketiga, yaitu tataran penceritaan (narration), para naratolog mulai lebih banyak mempertimbangkan teori pragmatik dalam ilmu bahasa/komunikasi. Menganalisis cerita dari tataran ini berarti berupaya melihat bahwa kejadian dan tokoh dalam cerita tidaklah dengan sendirinya hadir di sana, tetapi diceritakan oleh pencerita (narrator) kepada pecerita (narratee) (Ridho, 2013). Dikotomi pencerita dan pecerita 
mempunyai peran yang berbeda. Pencerita bisa kita dikatakan sebagai orang yang menceritakan sebuah riwayat kepada orang yang diceritai (pecerita). Pecerita adalah orang yang diceritai sebuah teks atau yang mendengar sebuah simakan dari pencerita. Berikut penjelasan dengan gambar

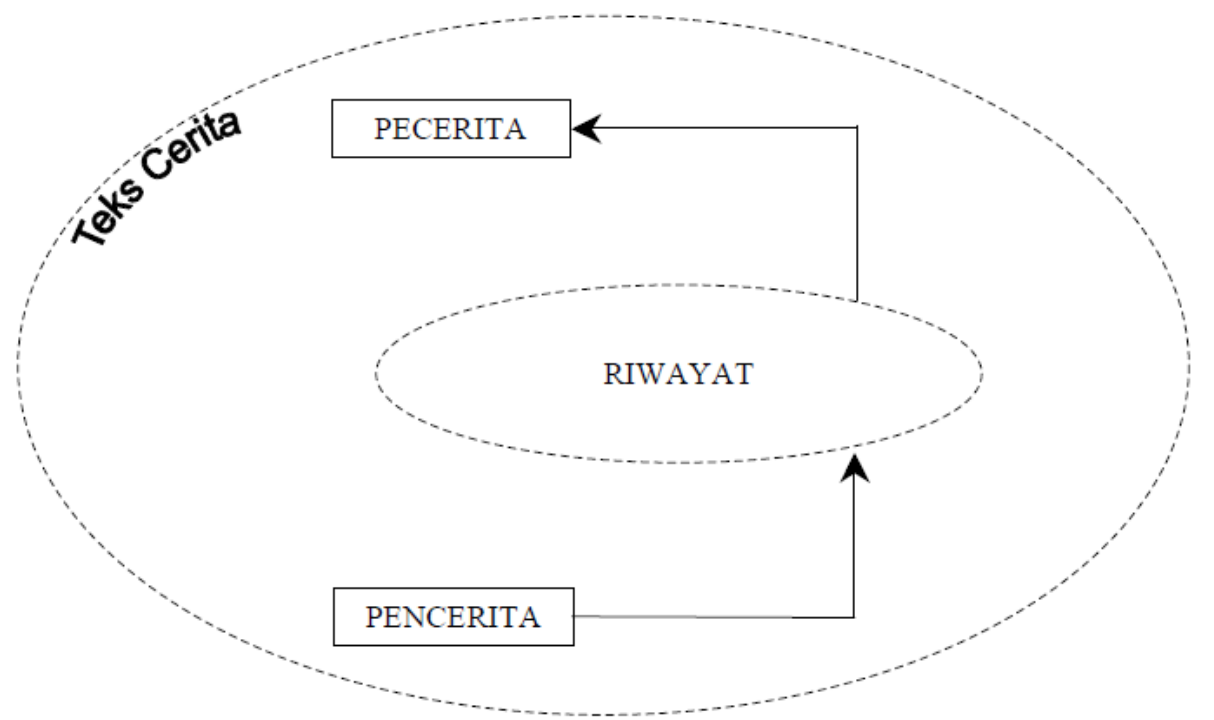

Gambae 1 hubungan teks riwayat, pencerita dan pecerita (Ridho, 2013)

Setelah mengalami beberapa tahap penting dalam pembentukan struktural menuju ke arah sastra dan subdisiplin ilmu lainnya, pada tahun 1966 Perkembangan studi sastra struktural rupanya lebih terlihat maju pesat dalam studi cerita. Pada tahun 1966, beberapa tokoh penting strukturalisme Prancis, yaitu Barthes, Greimas, Bremond, Eco, Genette, dan Todorov mengemukakan pandangan mereka dalam salah satu jurnal terkemuka, Communication, tentang studi cerita secara struktural. Menurut Herman dan Vervaeck (2001, 41), hal inilah yang memulai pembentukan bidang keilmuan "naratologi" oleh Todorov (Ridho, 2013).

Naratologi dalam ancangan Todorov mampu untuk menguak sebuah identitas seperti dalam studi Aimee Davis (2010) temtang orang Indonesia Tionghoa membentuk identitasnya di masa Orde Baru. Studi naratologi lainnya yang membahas masalah identitas dalam bingkai cerita adalah Nilan (2006) yang membedah feminis dengan sebuah bingkai naratologis. Kemudian ada Seno Gumira Ajidarma (2009) yang membahas Culture Studies dalam cerita silat Nagabumi dengan teknik yang sama, naratologi.

Setelah menjabarkan denah di atas, penulis akan memberikan beberapa contoh penerapan tentang arus kesadaran dari siapa yanng menjadi pencerita dan seperti apa orang yang menjadi pecerita dari novel "Semua Ikan di Langit" yang kita singkat menjadi SIdL karangan Ziggy Zezsyazeoviennazabrizkie yang diterjemahkan oleh Zuriyati;

Narration (pencerita) : Bus: Pertemuan kami dengan Shoshanna membuat perjalanan terhambat cukup lama. Anpa ikan julung-julung yang cuku banyak, saya tidak bisa terbang. (SidL, 52)

Narratee (pecerita) : Nad: "Kamu bukan Cuma berjalan keliling Bumi dan angkasa, bus tololku yang baik," kata Nad sambil mengusap lantai saya...”. (SIdL, 53) 
Perbedaan ada pada kata kunci "siapa yang bercerita" dari dikotomi pencerita dan pecerita. Sebuah simbol bus adalah yang adalah seorang pencerita dalam novel SIdL menuturkan bahwa "Pertemuan kami dengan Shoshanna membuat perjalanan terhambat cukup lama". Sementara sebagai seorang pecerita adalah "saya" (bus) yang disapa oleh Nad. Perasaannya ini boleh jadi mempunyai agenda untuk melanjutkan cerita tentang kehidpannya yang terbentang luas untuk menandakan episode selanjutnya agar bisa diikuti oleh para tokoh dan pembaca.

Pada gambar berikutnya penulis akan mencoba mengabstraksi tataran riwayat dari cerita novel SIdL;

PECERITA ( tokoh tokoh di dalam novel yang disapa oleh pencerita)

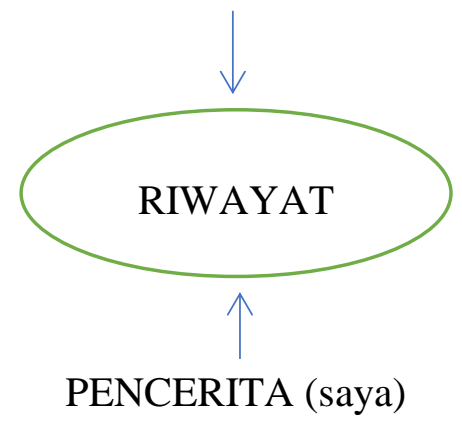

Pada gambar di atas menunjukkan bahwa peran pecerita dan pencerita menjadi hal yang memungkinkan untuk diceritakan lebih detail karena berdasarkan riwayat, pecerita adalah orang yang disapa kemudian diceritakan dalam sebuah teks oleh pencerita merujuk kepada Rimmon-Kenan.

By 'narative fiction' I mean the narration of a succession of fictional event....Te term narrartion suggests (1) a communication process in which the narrative as message is transmitted by addresser to addressee and (2) the verbal nature of the medium used to transmitt the message. It is tis that distinguishes narrative fiction from narratives in other media, such as film, dance, or pantomime.

Yang dimaksud dengan "cerita fiksi" adalah penceritaan serangkaian kejadian fiksi... Istilah penceritaan mengandung arti (1) proses komunikasi yang berlangsung ketika cerita sebagai pesan disampaikan oleh pencerita kepada pecerita dan (2) medium verbal yang digunakan untuk menyampaikan pesan tersebut. Medium inilah yang membedakan cerita fiksi dengan cerita yang menggunakan media lain, seperti film, tari, atau pantomim.) (Ridho, 2013).

Dari penjelasan di atas konsep dikotomi pencerita dan pecerita adalah memperlihatkan mana peran sebagai pencerita dan pecerita. Seorang pencerita adalah tokoh dalam sebuah cerita yang berdasarkan riwayat dan kronoogis ia bertindak sebagai seorang yang bercerita. Kemudian jika kita mencoba menceritakan bentuk pecerita maka ia adalah orang yang disapa atau yang akan diajak berbicara oleh narator di dalam teks atau cerita tersebut.

Setelah dikotomi pencerita dan pecerita telah dijelaskan, maka tahap selajutnya akan menjelaskan bentuk arus kesadaran atau persepsi atau biasa disebut istilah fokalisasi. Menurut Kutha Ratna (2015: 128) naratologi berasal dari bahasa Latin yaitu, dari kata naarratio yang berarti cerita, perkataan, kisah, hikayat, sedangkan logos berarti ilmu. 
Dengan demikian, naratologi dapat diartikan sebagai seperangkat konsep mengenai cerita dan penceritaan. Naratologi juga disebut teori wacana (teks) naratif karena dalam perkembangannya didasari atas analogi linguistik, seperti model sintaksis sebagaimana memiliki hubungan antara subjek, predikat, dan objek penderita. Lebih lanjut, menurut Genette (dalam Kutha Ratna, 2015: 254-255) pokok naratologi terbagi dalam lima hal, yaitu Order atau tata yang merupakan hubungan antara peristiwa-peristiwa nyata, peristiwa kronologis dengan peristiwa-peristiwa yang diatur kembali sebagai dekronologisasi, duration atau durasi merupakan hubungan antara waktu cerita yang telah berlalu, frekuensi (frequency) adalah hubungan potensial antara cerita dan pencerita sebagai repetisi, tutur (voice) membicarakan cerita, penceritaan, dan latar belakang sosialnya, dan modus (mood) adalah berbagai bentuk yang digunakan untuk menjelaskan intensitas yang dibicarakan. Satu aspek dalam modus adalah fokalisasi (focalization). Oleh karena itu, dalam penelitian ini pokok naratologi yang dipergunakan hanya fokalisasi yang lebih mendetail tentang persepsi dari pencerita dan pecerita.

Genette (dalam Nurgiyantoro, 2013: 339) menawarkan istilah fokalisasi (focalization), yang lebih dekat berhubungan dengan pengisahan. Fokalisasi berasal dari kata focus yang berarti unsur yang menonjolkan sesuatu, pusat pandang atau pusat perhatian. Menurut Luxemburg dkk., (1991: 125) fokalisasi itu sendiri menunjuk pada pengertian adanya hubungan antara unsur-unsur peristiwa dan visi yang disajikan kepada pembaca. Fokalisasi dalam kaitanya dengan posisi pencerita digolongkan oleh Luxemburg dkk. (1991: 117) menjadi dua jenis, yakni (1) fokalisasi intern dan (2) fokalisasi ekstern. Fokalisasi intern merupakan sudut pandang yang berasal dari dalam cerita yang dapat berupa cakapan langsung, ungkapan tokoh, solilokui (curahan hati seorang tokoh dengan berbicara seorang diri), lakuan (perbuatan atau tindakan) maupun ungkapan seorang penutur sedangkan fokalisasi ektern disebut juga sebagai sudut pandang menyeluruh karena sudut pandang tersebut melihat keseluruhan cerita. Fokalisasi ekstern berkaitan dengan pencerita atau teks pencerita.

Menurut Luxemburg dkk. (1991:125-126) fokalisator atau subjek fokalisasi dibagi menjadi tiga, yaitu fokalisator intern, fokalisator ektern, dan fokalisator kolektif. Fokalisator intern, adalah fokalisator yang berasal dari dalam cerita. Fokalisator ekstern adalah fokalisator yang berasal dari luar cerita. Fokalisator ekstern mengantarkan kita kepada sudut pandang berbagai tokoh. Fokalisator kolektif merupakan beberapa fokalisator yang memiliki sudut pandang sama dalam memandang sesuatu hal dalam cerita. Lebih lanjut, Luxemburg dkk. (1991: 134) menyatakan bahwa proses interpretasi cerita, latar hampir selalu menunjang makna cerita. Dengan demikian, fokalisasi memiliki hubungan yang erat dan tidak dapat terpisahkan dengan aspek latar terjadinya peristiwa. Keterkaitan fokalisasi dengan latar dapat dilihat melalui lakuan yang dimunculkan oleh tokoh. Pelukisan latar dalam cerita dapat berfungsi untuk memberi latar belakang realitas tertentu, mendapat makna dalam hubungannya dengan peristiwa (makna simbolik), atau bisa juga berfungsi ganda. Penentuan waktu dan tempat bisa saja menyatu dengan hanya memunculkan salah satunya, yakni memiliki sifat tempat, tetapi secara simbolik bersifat waktu, atau sebaliknya. Penentuan waktu dan tempat juga bisa menyatu melalui suatu tindakan yang muncul akibat fokalisasi atau persepsi.

\section{Dikotomi subjek dan objek Fokalisasi}

Tahap selanjutnya dari analisa naratologi adalah menentukan unsur-unsur fokalisor. Seperti yang sudah diketahui bahwa fokalisor adalah bentuk sub bagian dari tataran naratologi yang mennentukan arus sadar dari si pencerita. Istilah fokalisasi sebenarnya 
didasarkan pada konsep "persepsi" (Ridho, 2013). Peran persepsi menerangkan bahwa suatu cerita bisa dimaknai dari beberapa sudut pandang dalam seg penceritaan. Suatu sudut pandang bisa dilihat dari aspek narator dan fokalisor. Dalam tingkat persepsi, bisa jadi mempunyai beberapa alasan seperti contoh kaimat berikut: "Saya sangat senang ketika ia memakai topi". Kalimat ini mempunyai muatan persepsi dan refleksi, yakni ketika orang teersebut tersebut melihat si dia yang memakai topi, di satu sisi, dan "melihat" perasaan senang di dalam dirinya sendiri, di sisi lain. Persepsi pertama adalah dia memakai topi (bentuk ril) dan persepsi kedua menyatakan perasaan senang.

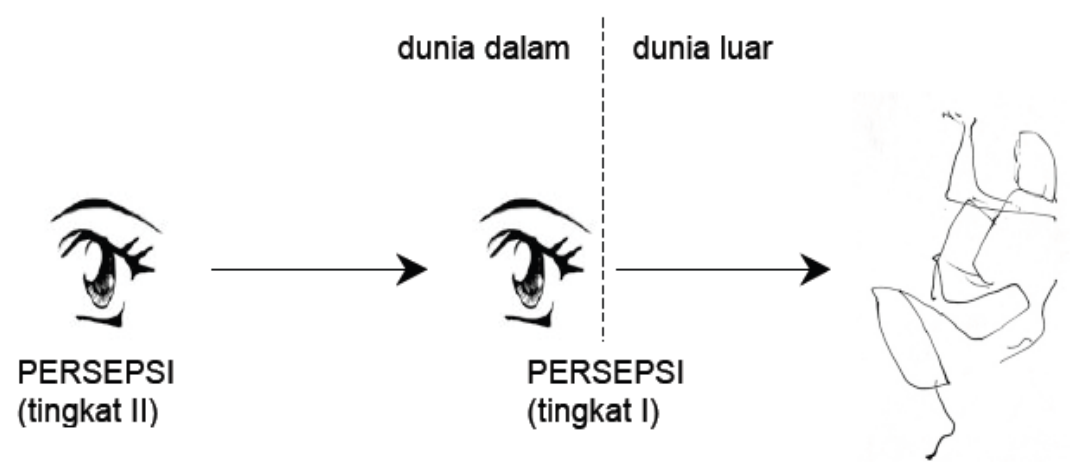

Gambar 2 persepsi tingkat I dan II (Ridho, 2013)

Setelah menerangkan tingkat peresepsi maka tahap selanjutnya adalah menetukan fokalisor (subjek) dan objek fokalisasi; fokalisasi internal dan eksternal; dan fokalisasi ke luar dan ke dalam (Ridho, 2013). Dalam teknik penceritaan fokalisor "saya" adalah sebuah perepsi yang memiliki arus kesadaran dari sebuah cerita. Ke "saya" ini mempunyai kesempatan untuk melihat, merasakan, dan mendengar kejadian yang menjadi objek dalam sebuah cerita yang dibentuk oleh sebuah cerita. Lain hal dengan subjek, objek fokalisasi adalah bentuk abstrak dari sebuah persitiwa. Sebuah peristiwa boleh jadi tidak mempunyai bentuk konkret ketika diterjemahkan ke dalam teks, ia hadir dalam bentuk ide dari si fokalisor. Bisa jadi berbentuk ingatan, perasaan, dan petunjuk yang membentuk sebuah kejadian. Berikut posisi subjek dan objek fokalisasi dalam novel SidL.

"Dan dari tangannya, saya akhirnya mendengar suara-suara Beliau. Dan saya hanya menemukan jawaban dai pertanyaan yang sudah sama sekali saya tanyakan: Mengapa beliau tidak pernah mau menapakkan kakinya dan berbincang-bincang dengan saya? Bukan karena Beliau tidak ingin dimengerti oleh saya, melainkan karena Beliau memiliki lebih banyak pengetahuan, lebih banyak pemikiran daripada Chinar dan anak-anaknya, dan selebihnya, yang hidup dan yang mati”.

Subjek kesadaran (fokalisor) di atas adalah "saya" yang mempunyai perasaan dan ingatan tentang Beliau yang mempunyai "memiliki lebih banyak pengetahuan, lebih banyak pemikiran'. Hal inilah yang dijadikan sebagai obyek fokalisasi karena timbul daari perasaan dan ingatan berdasarkan cerita-cerita sebelumnya tentang beliau. Objek fokalisasi ini berdasarkan unsur penilaian pribadi dari seorang fokalisor (saya) mengenai Beliau. Skema fokalisor dan objek fokalisor jika dibuat bentuk bagan maka sebagai berikut: 
Fokalisor (saya) $\longrightarrow \quad$ Fokalisor (saya) + Objek fokalisasi

Perasaan dan ingatan

"saya" terhadap Beliau

\section{Fokalisasi internal dan eksternal}

Dalam Fokalisasi internal beberapa hal yang bisa dilihat ketika menentukan bentuk ini adalah sebuah perbedaan antara kejadian di luar dan di dalam. Kejadian di dalam (internal) merupakan sebuah bentuk fokalisasi yang kejadiannya dirasakan betul oleh si "saya". Kemudian fokalisasi eksternal adalah bentuk fokalisasi yang di dalamnya terdapat kejadian yang dibicarakan oleh pihak lain di luar si "saya" tersebut yang seolah-olah ikut merasakan peristiwa tersebut. Lalu fokalisasi eksternal adalah sebuah teknik penceritaan yang seolah-olah si pencerita berada pada peristiwa tersebut. Indikasi yang melekat kuat pada dalam ceita berupa ingatan dan pengalaman dari si narator kepada tokoh lainnya

Lain hal jika melihat dari fokalisor internal, maka fokalisor eksternal adalah tokoh baru yang dibentuk oleh narator. Dalam cerpen "Hikayat Siti Rahima" (HSR) ada indikasi fokalisor eksternal tokoh "akuan" yang memerankan sebatang pohon asam kemudian "akuan" yang lainnya adalah seorang perempuan (Ridho, 2013). Pada paragraf pertama, fokalisornya adalah "aku" yang mengaku dirinya adalah sebatang pohon asam. Dia mengakui hal itu di hadapan tokoh lain yang disebutnya, "Tuan". Pengakuan ini merupakan sebuah kejadian di awal cerpen, dan si "aku" merupakan salah satu tokoh yang berada di dalam kejadian tersebut bersama dengan tokoh "Tuan". Karena itu, fokalisasi pada paragraf pertama ini adalah fokalisasi internal. Semua objek fokalisasi pada paragraf pertama ini-yaitu perasaan senang dalam dirinya ketika bercerita, orang-orang yang tertidur di gerowong tubuh si "aku", dan si "Tuan" yang kini berada di hadapannyasemua itu dilihat dalam kesadaran si "aku" sebagai fokalisor internal.

Namun, pada paragraf kedua, si "aku" yang pohon asam ini tiba-tiba mengambil jarak terhadap dirinya yang lain, yaitu si "aku" yang manusia. Mulailah dia bercerita tentang dirinya ketika menjadi manusia. Maka, di sini muncul tokoh baru, yaitu si "aku" yang manusia. Si "aku"-manusia tersebut menjadi objek fokalisasi, sedangkan fokalisornya adalah si "aku"-pohon asam. Karena itu, fokalisasi berpindah menjadi fokalisasi eksternal karena kini si "aku"- pohon asam meletakkan dirinya di luar kejadian yang menimpa si "aku"-manusia. Sejak dari paragraf kedua ini, seluruh kejadian yang menimpa si "aku"-manusia beserta kejadian di awal perubahannya menjadi pohon asam, semuanya dilihat melalui fokalisasi eksternal, yaitu dari fokalisor si "aku"-pohon asam. Dalam konteks ini, bisa juga dikatakan bahwa si "aku" pohon bertindak tidak hanya sebagai fokalisor tetapi sekaligus pula sebagai narator.

\section{Fokalisasi Dari Dalam dan dari Luar}

Kemudian penentuan fokalisasi yang terakhir adalah ke dalam dan ke luar. Fokalisasi ke dalam dan keluar didasarkan pada sejauh mana fokalisor bisa mendeskripsikan aspekaspek yang berada pada objek fokalisasinya. Misalkan tokoh "saya" (Bus) dalam novel Sidl menjadi fokalisor internal karena mendeskripsikan Beliau. "Beliau lalu mengambil sebuah wadah kecil berbentuk kotak yang berwarna cokelat. Dari dalamnya keluar benda kecil berbentuk tak beraturan, dengan lubang-lubang di sekujur permukaannya, berwarna 
emas terang. Potongan sarang lebah. Dibawa julung-julung ke tengah-tengah lingkaran permen. Jejak mereka menimbulkan garis panjang di bawah pusaran gula-gula tadi." . Fokalisor hanya mampu untuk mendekripsikan aspek lahiriah dari Beliau yang objek fokalisornya adalah kegiatan Beliau.

Dalam aspek fokalisasi ke luar misalnya dalam cerpen "Potret Keluarga". Saya ambilkan paragraf ketiganya: "Maka kini Marni memandangi potret keluarga itu. Sudah agak buram sebenarnya, bahkan telah berwarna cokelat tua, tidak hitam-putih lagi. Marni meluruskan kakinya di kursi malas - kursi malas terbuat dari rotan yang sudah reyot. Ia ingat kursi malas itu dulu milik kakeknya, tempat kakeknya juga suka meluruskan kaki,..." (hlm. 33). Fokalisasi pada bagian ini adalah fokalisasi eksternal, tetapi fokalisor eksternal itu ternyata tidak hanya melihat dari luar ke arah Marni yang sedang memandangi potret keluarganya, tetapi juga seolah-olah masuk ke dalam diri Marni dan mengetahui hal yang sedang diingat Marni, yaitu tentang kebiasaan kakeknya duduk di kursi malas itu. Jadi, dalam contoh ini, tidak hanya aspek lahiriah yang dilihat, tetapi juga aspek batin dari obyek fokalisasi tersebut. Inilah yang disebut fokalisasi dari dalam (Ridho, 2013).

\section{METODE PENELITIAN}

Menurut Kutha Ratna (2015: 34) metode berfungsi untuk menyederhanakan masalah, sehingga lebih mudah untuk dipecahkan dan dipahami. Oleh karena itu, metode pengumpulan data yang digunakan dalam penelitian ini adalah metode kepustakaan. Sugiyono (2015: 291) menyatakan bahwa studi kepustakaan berkaitan dengan kajian teoretis dan referensial lain yang berhubungan dengan nilai, budaya, dan norma yang berkembang pada situasi sosial yang diteliti.

Menurut Riffaterre (dalam Bramantio, 2010: 28) pembacaan karya sastra dilakukan dengan dua tahap. Pembacaan tahap pertama disebut dengan pembacaan heuristik. Dalam pembacaan heuristik kompetensi kebahasaan dan kesastraan memainkan peranan penting. Pembacaan tahap kedua disebut pembacaan hermeutik. Pada tahap kedua ini terjadi proses interpretasi yang sesungguhnya. Pembaca berusaha melakukan perbandingan berkaitan dengan yang telah dibaca pada saat pembacaan tahap pertama.

Setelah melalui tahapan membaca dan menemukan kutipan-kutipan yang berkaitan dengan objek penelitian, kutipan tersebut dicatat. Kutipan-kutipan berupa tuturan dan lakuan fokalisator yang berkaitan dengan jenis-jenis fokalisasi serta keterkaitan fokalisasi dengan unsur-unsur intrinsik lainnya dicatat pada kartu data. Teknik catat digunakan agar data yang berhasil dikumpulkan terjamin kebenarannya.

Data yang telah diperoleh melalui pembacaan dan pencatatan tersebut, selanjutnya data dianalisis. Analisis data penelitian ini menggunakan metode deskriptif analitik. Kutha Ratna (2015: 53) menyatakan bahwa metode deskriptif analitik dilakukan dengan cara mendeskripsikan fakta-fakta yang kemudian disusul dengan analisis. Analisis tidak semata-mata menguraikan, melainkan juga memberikan pemahaman dan penjelasan secukupnya sesuai dengan fokus penelitian. Langkah-langkah yang ditempuh dalam analisis ini, yaitu membaca kartu data yang berisi kutipan tuturan dan lakuan fokalisator yang berkaitan dengan fokalisasi, menganalisis fokalisasi yang terkandung dalam novel Tempurung, mengklasifikasi jenis-jenis fokalisasi yang ditemukan, menguraikan dan memperjelas jenis-jenis fokalisasi yang ditemukan dengan menyertakan kutipan, menguraikan dan memperjelas keterkaitan fokalisasi dengan unsur intrinsik lainnya, dan Lebih lanjut, data yang sudah dianalisis kemudian akan disajikan. Metode penyajian hasil analisis data dilakukan dengan metode formal dan metode informal. Sudaryanto (2015: 
241) menyatakan bahwa metode penyajian formal adalah perumusan hasil penelitian yang disajikan dengan tanda dan lambang-lambang, sedangkan metode penyajian informal adalah penyajian hasil penelitian dengan pemaparan kata-kata biasa secara tertulis. Metode yang digunakan dalam penelitian ini adalah metode informal dengan pemaparan kata-kata, sementara metode formal berupa tabel bersifat sebagai pembentuk data hasil penulisan.

\section{HASIL DAN PEMBAHASAN}

\section{Penentuan Subjek dan Objek Fokalisasi}

Dalam penentuan subyek aspek "saya" sangat mendominasi dari keseluruhan cerita. Subjek "saya" adalah sebuah bus yang merupakan tokoh utama dari novel ini yang berisikan sejumlah personifikasi (penghidupan) benda-benda mati dan binatang yang mempunyai perasaan dan akal layaknya manusia. Subjek "saya" sebagai sebuah bus yang sangat ingin dicintai oleh Beliau. Berbagai deskripsi dalam novel ini sangat mencerminkan aspek Beliau yang kharismatik. Berikut adalah tabel temuan hasil subjek dan objek fokalisasi.

\begin{tabular}{ll}
\hline Subjek (fokalisor) & \multicolumn{1}{c}{ Objek Fokalisasi } \\
\hline "saya" (bus) & Perasaan ingin dicintai Beliau (SIdL, 267) \\
"saya" (bus) & Keheranan dengan tokoh Bastet Sang Dewa \\
& Kucing (SidL, 54) \\
"saya" (bus) & Kecoa yang anggun gerak-geriknya. Tenang dan \\
& berwibawa (SIdL, 25) \\
Chinar & Ingatan tentang beliau terhadap hal-hal yang tida \\
Char & disukainya. (SidL,152) \\
& Ingatan tentang Beliau yang memusnahkan hal-hal \\
& yang tidak disukainya. (SIdL, 181) \\
\hline
\end{tabular}

"Beliau memang tidak berkata-kata. Tapi tindakannya menunjukkan bahwa Beliau menyayangi saya. Ah, mungkin memang inilah cara orang-orang yang sukar dipahami menunjukkan rasa sayang mereka. Bus biasa seperti saya hanya bisa memaklumi keterbatasan mereka dalam meyampaikan perasaan -itu juga adalah bentuk rasa sayang, dan saya rasa, yang paling bagus di antaranya”.

Subjek (fokalisor) dalam kutipan ini adalah "saya" tentang perasaan dari Beliau tentang dirinya ditandai sebagai Objek fokalisasi karena "saya" menyadari seolah-oleh Beliau suka dengannya.

\section{Fokalisasi internal dan eksternal}

Dari hasil penelitian ini didapat berupa bentuk- bentuk subyek dan objek fokalisasi, fokalisor internal dan eksternal pada bab yang tediri dari 39 cerita ini. Dalam penentuan fokalisasi internal dan eksternal, penulis menentukannya dengan mencari cerita dari si "Saya" yang menjelaskan berbagai peristiwa yang dialami sendiri atau orang lain, dialog, atau berbicara dalam hati (solilokui).

\section{Fokalisasi Internal}

Klakson saya berbunyi nyaring karena terkejut ,Nad mendengking. Saya tidak pernah mendengar kecoa mendengking sebelumnya. (SIdL ,73) 
Saya melihat Beliau mendekati gadis itu dan pelan-pelan membawanya ke dalam saya. Anak itu menapakkan kakinya tapi hanya sedikit sekali yang ia ceritakan pada asya. Hanya ingatan terakhirnya: ditampar oleh ibunya, melarikan diri ke taman, bermainan ayunan berhari-hari sampai akhirnya dia berayun terlalu jauh dan terlempar ke luar angkasa. (SIdL,75)

Ah Beliau yang baik. Beliau bisa meakukan apa saja yang Beliau inginkan di dunia tapi Beliau tetap mau saja memili untuk melakukan sesuatu supaya bisa menyenangkan orang gendut yang tidak ada artinya ini (SidL, 115)

Serpihan tubuh saya yang terakhir adalah sebatang besi tipis yang menyerupai lidi pendek. Sebelum terjatuh, Beliau mengulurkan tangannya dan menangkap serpihan itu." (SIdL, 239)

Saya mencintai Beliau. Lebih dari segalanya di dunia ini, dan di seluruh duni ayng ada, pernah ada, dan akan ada. Hancur berkeping-keping demi mempertahankan perasaan cinta yang begitu kuat bukanlah hal besar ketika tidak ada ha lain yang lebih penting dari rasa itu. Kehancuran diri ini tidak berarti apa-apa bagi saya, karena saya hancur demi dirinya (SidL, 241)

Beberapa tuturan di atas yang penulis kutip dari beberapa kutipan dalam novel ini terlihat aspek fokalisasi internal yang banyak terlihat untuk mendeskripsika perasaan "saya" pada objek fokalisasinya adalah Beliau. Fokalisasi internal memang sudah terlihat pada saat pendeskripsian Beliau dan kemudian hampir semua keterlibatan peristiwa, sosok "saya" selalu ada. Apakah ia menjadi pendengar, terlibat dialog, dan berbicara pada diri sendiri adalah semua aspek yang mempertegas bahwa fokalisasi internal menjadi dominan dalam novel ini.

\section{Fokalisasi ke luar dan dari dalam}

Dalam peristiwa novel SidL, aspek fokalisasi dalam muncul saat perasaan dari "saya" memulai perasaannya dan ingin masuk ke dalam hati Beliau namun ia tidak bisa mengetahui seberapa besar perasaan yang sama dari Beliau kepada "saya". Hal ini menandai sebuah aspek ke luar dengan indikasi tokoh Beliau tidak mau menyatakan perasaannya, ia hanya menunjukkan perilaku sehari-hari yang ia biasa lakukan (lahiriah). Sebuah penceritaan awal yang menandai permulaan petualangan yang menyenangkan tanpa ada berfungsi sebagai fokalisasi ke dalam. Proses fokalisasi ke dalam terdapat pada beberapa kaimat, Beliau tampaknya sangat gembira berada di foto pembuat sepatu. Beliau berkeliling, dengan ikan-ikannya (SidL, 2).

\begin{tabular}{|c|c|}
\hline Fokalisasi ke luar & Fokalisasi ke dalam \\
\hline $\begin{array}{l}\text { Beliau membawa kami ke tempat yang } \\
\text { sangat menarik kali ini. Ada sebuah } \\
\text { lemari raksasa yang membentuk cincin, } \\
\text { mengapung dekat dengan planetoid } \\
\text { suram. Di setiap jengkal lemari itu, diisi } \\
\text { berbagai macam piring, cangkir, } \\
\text { mangkuk, stoples, botol, kaleng, dan } \\
\text { berbagai wadah yang menampung } \\
\text { macam-macam benda berwarna-warni } \\
\text { (SidL, 65) }\end{array}$ & $\begin{array}{l}\text { Perjalanan ini membuat saya menyayangi } \\
\text { Beliau. Bahkan, meskipun Beliau tidak } \\
\text { berkata-kata langsung kepada saya. Ada } \\
\text { sesuatu yang membuat saya merasa bahwa } \\
\text { saya begitu dekat dan begitu mengenal } \\
\text { Beliau. Namun, pada saat bersamaan, saya } \\
\text { tahu bahwa Beliau begitu jauh dari } \\
\text { jangkauan saya, dan saya tidak akan pernah } \\
\text { benar-benar memahami dirinya (SidL, 64). }\end{array}$ \\
\hline
\end{tabular}




\begin{tabular}{|c|c|}
\hline $\begin{array}{l}\text { Beliau tidak memakai sepatu. Ini } \\
\text { baru saya sadari ketika melihat ikan-ikan } \\
\text { menyamar jadi sepatu bot untuknya. } \\
\text { Yahh, mungkin Beliau memang tidak } \\
\text { memerlukan sepatu. Dia kan bisa } \\
\text { menapak di tanah. Kulit di telapak } \\
\text { kakiya tidak akan tanpa sengaja } \\
\text { meginjak pecahan kaca atau permen } \\
\text { karet (SidL, 114). }\end{array}$ & \\
\hline $\begin{array}{l}\text { Yah, kalau Beliau mau, Beliau } \\
\text { memang bisa membungkam keusilan } \\
\text { anak jahat itu. Tapi, mungkin orang- } \\
\text { orang yang tidak meminta pertolongan } \\
\text { Beliau tidak akan pernah jadi prioritas } \\
\text { Beliau. Mungkin karena itu ada orang- } \\
\text { orang yang mati dilindas mobil, ada yang } \\
\text { tetap terlelap di kasurnya dalam tidur } \\
\text { tanpa mimpi. (SidL, 219) }\end{array}$ & $\begin{array}{l}\text { Ah orang aneh. Dia bertanya-tanya } \\
\text { kenapa oran-orang bilang dia } \\
\text { membingungkan, sampai memanggil dia } \\
\text { "Membingungkan", padahal jawabannya } \\
\text { jelas sekali: karena dia orang aneh - dan } \\
\text { memang membingungkan betul tingkah } \\
\text { lakunya. Yah, apa boleh buat. Orang yang } \\
\text { sungguh-sungguh aneh (SidL, 208) }\end{array}$ \\
\hline
\end{tabular}

Bagian fokalisasi ke dalam memang sulit untuk ditentukan karena "saya" menceritakan seolah-olah tahu dan prediksi yang akan diperbuat oleh pelaku lainnya. Dalam fokalisasi dalam, "saya" seolah-olah terlibat dalam pergolakan batin dari tokoh yang ada dalam novel tersebut. Unsur ini terkadang yang memberikan deskripsi secara detil dari seorang pengarang.

Ciri Perwatakan Dalam Novel SidL

Pola fokalisasi

\begin{tabular}{|c|c|c|c|}
\hline Arus & $\begin{array}{c}\text { Subjek/objek } \\
\text { fokalisasi }\end{array}$ & Internal /Eksternal & Ke Luar/ ke Dalam \\
\hline Berubah & I & III & V \\
\hline Tetap & II & IV & VI \\
\hline
\end{tabular}

Dari hasil kajian di atas, maka tipe fokalisasi yang sesuai dari hasil penelitian ini adalah pola II dan III. Pola ini hanya mengalami perubahan dari segi internal dan eksternal, namun tuturan "saya" dominan dari keseluruhan data yang diambil dari 39 bab ini. Dan fokalisasi pun mengalami perubahan yang signifikan pula karena pepindahan dari aspek perasaan "saya" yang hanya ia yang mengetahui kini pindah karena kecemasan yang mempunyai hubungan kausal. Maka dalam hal ini pola yang dipakai dalam novel SidL ini adalah, I, IV, dan V.

\section{SIMPULAN}

Dari hasil penelitian di atas dapat disimpulkan bahwa kajian naratologi bukan mengkritik atau membandingkan mana yang labih baik dalam hal penceritaan. Kajian ini hanya menguraikan penceritaan sebuah bentuk dalam teks lewat tuturan dari tokoh-tokohnya. Pengkhususan kajian ini terletak pada pentingnya aspek keterbacaan cerita dari sebuah karya tersebut sehingga mampu memunculkan beragam teknik dan bahkan maksud dari seorang pengarang "memainkan" teknik dalam bercerita. Aspek temuan yang dinamis 
menandakan bahwa pengarang sudah mempunyai pemetaan yang detail dan jelas ketika memainkan arus (fokalisasi) dari berbagai macam tokoh, sehingga dari deskripsi tersebut bisa dikembangkan menjadi sebuah ideologi, gender, bahkan feminisme dari cara tiap tokoh bercerita.

\section{DAFTAR PUSTAKA}

Bal, M. (1997). Narratology: Introduction to the theory of narrative, second companion to narrative theory. MA: Blackwell. Cornell University Press. dan Pustaka Malaysia.

Davis, A. (2010). Orang Indonesia Tionghoa mencari identitas. Jakarta: Edition. Toronto: University of Toronto Press.

Dewii, N. P. Y. (2018). Fokalisasi Novel Tempurung Karya Oka Rusmini dan Relevansinya dalam Pembelajaran Sastra di SMA/SMK. Bali: Stilistika Volume 7 (1), Fakultas Pendidikan Bahasa dan Seni, IKIP PGRI Bali

Fludernik, M. (2005). Histories of narrative theory (II): From Structuralism

Genette, G. (1980). Narrative discourse: An essay in method. New York: Gramedia.

Ratna, N. K. (2015). Teori, metode, dan teknik penelitian sastra. Yogyakarta: Pustaka Pelajar.

Luxemburg dkk. (1991). Tentang sastra. Penerjemah: Akhadiati Ikram. Jakarta: Intermasa.

Nurgiyantoro, B. (2013). Teori pengkajian fiksi. Yogyakarta: Gajah Mada University Press.

Propp, V. (1987). Morfologi cerita rakyat. Kuala Lumpur: Dewan Bahasa.

Ridho, I. (2013). Kajian prosa fiksi. Jakarta: Universitas Negeri Jakarta.

Rimmon-Kenan, S. (2002). Narrative fiction. Second Edition. London: Routledge.

Sugiyono. (2015). Metode penelitian pendidikan: Pendekatan kuantitatif, kualitatif, dan $R \& D$. Bandung: Alfabeta. to the Present. Dalam James Phelan dan Peter J. Rabinowitz (Ed.), A 